Jurnal

Kardiologi Indonesia

J Kardiol Indones. 2013;34:188-96

ISSN $0126 / 3773$

\title{
Sindroma Pre Eksitasi Asimtomatik: Ablasi Versus Konservatif
}

Department of Cardiology and Vascular Medicine, Faculty of Medicine, University of Indonesia and National Cardiovascular Center Harapan Kita, Jakarta.

\author{
Dian Andina Munawar, Yoga Yuniadi
}

Wolff-Parkinson-White (WPW) is a sporadic and familial abnormality. Epidemiological data indicate that $0.1 \%$ to $0.3 \%$ of the general population have ECG findings suggesting that during sinus rhythm. The risk of sudden cardiac death is around $0.25 \%$. Patients with WPW syndrome is often symptomatic because of cardiac arrhythmias. Sometimes the arrhythmia can be life-threatening, and leads to sudden cardiac death. However, there is still controversy in management of individuals with asymptomatic WPW pattern. Despite radiofrequency catheter ablation remains the first line therapy of the WPW syndrome, the risk of complications of this procedure is almost the same as the risk of sudden cardiac death in asymptomatic WPW. Therefore, an algorithm to determine the appropriate management of asymptomatic WPW patients is needed.

(J Kardiol Indones. 20 I3;34: I88-96)

Keywords: preexcitation syndrome, ablation, conservative 


\title{
Sindroma Pre Eksitasi Asimtomatik: Ablasi Versus Konservatif
}

\author{
Dian Andina Munawar, Yoga Yuniadi
}

\begin{abstract}
Sindrom preeksitasi pada Wolff-Parkinson-White (WPW) bersifat sporadik dan familial. Prevalensi pada populasi diperkirakan sekitar 0,1-0,3\%. Risiko terjadinya kematian jantung mendadak sekitar 0,25\%. Gejala yang dialami pasien WPW terjadi karena adanya aritmia jantung, yang dapat mengancam jiwa. Pada individu dengan gambaran WPW yang asimtomatik, masih terdapat kontroversi mengenai tatalaksana yang tepat. Kateter ablasi merupakan terapi definitif terhadap adanya sindrom WPW, namun risiko komplikasi akibat tindakan hampir sama dengan risiko timbulnya kematian jantung mendadak pada WPW yang asimtomatik. Oleh karena itu, diperlukan suatu algoritma untuk menentukan tatalaksana yang tepat bagi pasien WPW yang asimtomatik.
\end{abstract}

(J Kardiol Indones. 2013;34:188-96)

Kata Kunci: Sindrom preeksitasi, ablasi, konservatif

\section{Pendahuluan}

Pada tahun 1930, Wolff, Parkinson, dan White menjelaskan sebuah sindrom yang terdiri atas PR interval pendek dengan blok Bundle branch pada EKG dengan manifestasi klinis takikardia paroksismal. Namun korelasi antara anatomi dan elektrofisiologi penemuan tersebut tidak dijelaskan. Holzman an Scheff merupakan orang pertama yang menjelaskan pathogenesis sindrom Wolff-Parkinson-White (WPW) yang melibatkan sirkuit reentrant yang melibatkan AV node dan accessory pathway (AP) ekstranodal. ${ }^{1}$ Secara klasik, pasien dengan sindrom WPW memiliki pre-

\section{Alamat Korespondensi:}

Dr. dr. Yoga Yuniadi, SpJP. Departemen Kardiologi dan Kedokteran Vaskular, Fakultas Kedokteran Universitas Indonesia dan Pusat Jantung Nasional Harapan Kita, Jakarta. Email: yogayl36@gmail.com sentasi palpitasi atau presinkop yng disebabkan oleh atrioventricular reciprocating tachycardia (AVRT) atau atrial takikardia. Atrial fibrilasi (AF) dengan respons cepat akan memicu terjadinya ventrikel fibrilasi (VF) yang seringkali menjadi presentasi klinis pertama dari sindrom WPW., meski dalam usia muda. ${ }^{2}$

Prevalensi sindrom WPW diperkirakan antara $0,1-0,3 \%$ pada populasi. Dasar genetik terjadinya preeksitasi belum sepenuhnya diketahui. Sindrom preeksitasi pada WPW bersifat sopradik, familial, dan berhubungan dengan kardiomiopati hipertropik, atau penyakit congenital lain seperti Ebstein, atau transposisi arteri besar. ${ }^{3}$ Studi familial menunjukkan insidens 5.5 per 1000 orang terhadap saudara langsung pasien dengan WPW. ${ }^{4}$ Risiko terjadinya kematian jantung mendadak (KJM) pada pasien dengan sindrom WolffParkinson-White (WPW) diperkirakan sekitar 0,25\% per tahun atau 3-4\% seumur hidup. Namun, KJM dapat merupakan presentasi klinis pertama pada pasien 
dengan preeksitasi asimtomatik. Kuantifikasi yang akurat mengenai risiko kematian yang dapat terjadi masih kontroversial. ${ }^{3}$

Pasien dengan EKG yang memiliki bentuk WPW dibagi mejadi 3 grup dengan perbedaan pertimbangan tata laksana. Pertama, pasien dengan asimtomatik, pasien dengan takikardia supraventrikel (TSV) spontan, atau pasien yang datang dengan presentasi AF. Saat ini manajemen pasien WPW asimtomatik masih kontroversial, mengenai apakah pasien tersebut membutuhkan pemeriksaan dan tatalaksana lebih lanjut. Guideline terbaru tadhun 1995 tidak merekomendasikan studi elektrofisiologi rutin pada pasien dengan WPW asimtomatik. Pasien yang memiliki pekerjaan dengan risiko tinggi merupakan pengecualian. ${ }^{5}$

Pada tinjauan pustaka ini akan dibahas mengenai patofisiologi dan pendekatan tata laksana pada pasien dengan EKG bentuk WPW yang asimtomatik.

\section{Patofisiologi sindroma WPW}

Pola WPW merupakan bentuk abnormalitas EKG karena adanya accessory pathways (AP), yang ditandai dengan pemendekan interval PR dan gelombang delta. Sedangkan sindrom WPW merupakan gabungan pola EKG WPW dengan takiaritmia. ${ }^{6}$ Mayoritas pasien WPW memiliki anatomi kardiak yang normal. AP merupakan suatu sisa embriologi. ${ }^{4}$ Oleh karena AP tidak memiliki konduksi yang bersifat decrement, maka AP biasanya memiliki konduksi yang lebih cepat daripada AVN, onset aktivasi ventrikel lebih cepat daripada depolarisasi yang hanya terjadi melalui AVN, yang menyebabkan pemendekan interval PR (P-delta). Konduksi preeksitasi intraventrikel pada WPW menyebar dari AP sebagai jalan masuk pada miokard ventrikel, melalui konduksi otot ke otot secara langsung. Proses ini berjalan lebih lambat daripada depolarisasi ventrikel normal. Jadi meskipun eksitasi terjadi awal ventrikel (via BT) terjadi lebih cepat, kemudian diikuti aktivasi miokard ventrikel yang lebih lambat daripada normal. Kompleks QRS yang terjadi terdiri atas gabungan antara aktivasi ventrikel akibat preeksitasi yang terjadi lebih cepat dan transmisi melalui AVN dan aktivasi His-ventrikel yang lebih lambat. Bagian awal kompleks QRS yang membentuk 'slurred' yang disebabkan aktivasi otot ke oto yang lambat dinamakan "gelombang delta". Semakin cepat konduksi melalui AP, makan jumlah miokard yang terdepolarisasi melalui AP semakin banyak, sehingga menyebabkan bentuk gembang delta yang makin lebih dan jelas, serta pemanjangan kompleks QRS. ${ }^{6}$

AVjunction merupakan lokasi di mana muskulatur atrium memasuki lingkaran katup mitral dan tricuspid. Struktur tersebut menghubungkan rongga atrium dan ventrikel. Komponen septal dari struktur tersebut merupakan satu-satunya struktur muscular yang dapat mengkonduksi impuls dari atrium ke ventrikel. AP dapat mneghubungkan atrium dan ventrikel dan dapat melewati $A V$ groove di mana pun pada anulus trikuspid atau mitral, kecuali pada trigonum jaringan ikat kanan dan kiri dimana atrium kiri tidak berada pada juxtaposisi langsung dengan miokard ventrikel kiri. $A V$ groove dibagi atas kuadran yang terdiri dari free wall kiri, free wall kanan, posteroseptal, dan anteroseptal. (Gambar 1). AP yang multipel terjadi 5-10\% pasien. AP didefinisikan multipel jika terpisah lebih dari 1-3 $\mathrm{cm}$. Kombinasi paling sering dari multipel BT antara lain posteroseptal free wall kanan. ${ }^{6}$

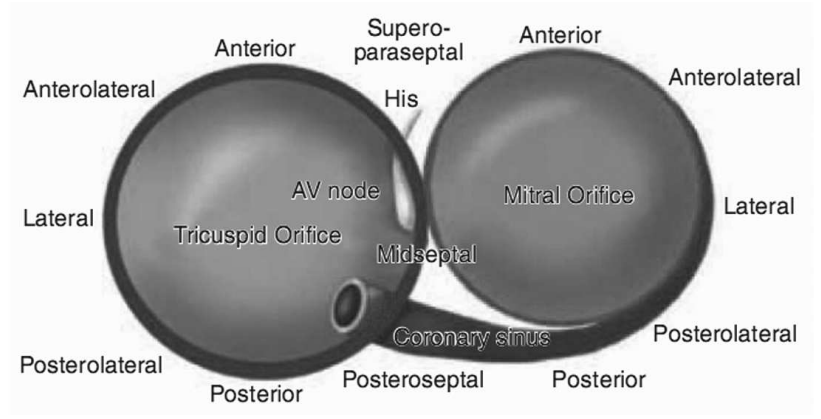

Gambar 1. Lokasi AP berdasarkan anatomi. Anulus mitral dan trikuspid dilihat dari LAO oblik. Terlihat lokasi sinus koronarius, AVN, dan His bundle. AP dapat menghubungkan atrium ke ventrikel pada regio tersebut.

Meskipun mayoritas AP dapat konduksi secara anterograde dan retrograde (bidireksional), beberapa AP hanya dapat menghantarkan impuls secara unidireksional. AP yang hanya dapat konduksi secara anterograde sangat jarang (kurang dari 5\%), sering melewati $A V$ groove, dan seringnya memiliki konduksi decremental. Sebaliknya, AP dengan konduksi secara retrograde terjadi lebih sering (17-37\%). Pada AP dengan konduksi anterograde, preeksitasi ventrikel terlihat saat irama sinus, dinamakan "manifest". Sedangkan AP dengan konduksi retrograde saja dinamakan "concealed".

Pada AP, depolarisasi terjadi karena arus natrium masuk cepat (rapid inward natrium current), yang serupa dengan jaringan His-purkinje, serta miokard 
atrium dan ventrikel. Sehingga AP anterograde maupun retrograde memiliki konduksi yang konstan pada segala LJ sampai periode refrakter tercapai, yaitu saat terdapat blok total (konduksi non-decrement). Jadi pada AP terdapat hukum all or none. Sebaliknya pada AVN, yang bergantung pada arus kalsium masuk lambat (slow inward calcium current) untuk membentuk potensial aksi, terlihat konduksi yang decremental di mana waktu konduksi melalui AVN akan meningkat jika panjang siklus memendek. Konduksi atrioventrikular akan lebih cepat melalui AP daripada AVN. Secara klinis perbedaan ini akan sangat penting, karena fungsi primer AVN adalah membatasi jumlah impuls yang dihantarkan dari atrium ke ventrikel pada laju atrium yang cepat. (contoh: atrial flutter). Pada AP, aritmia ini akan membuat laju ventrikel sangat cepat yang akan menimbulkan ventrikel fibrilasi. ${ }^{6}$

\section{Pembagian Atrioventricular Reentrant Tachycardia (AVRT)}

AVRT merupakan takikardia makroreentrant yang berbeda, yang secara anatomis terdiri atas dua pathway, yaitu sistem AVN yang normal, serta AP yang menghubungkan atrium dan ventrikel. Jika terdapat percedaan waktukonduksi dan refrakter pada AVN dan AP, maka impuls prematur yang berasal dari ventrikel maupun atrium dapat menginisiasi reentry. AVRT merupakan takikardia yang berhubungan dengan sindrom WPW. Pembagiannya antara lain: ${ }^{6}$

\section{AVRT Ortodromik}

Pada AVRT ortodromik, AVN-His merupakan jalur anterograde dari sirkuit reentri, dan AP berfungsi sebagai jalur retrograde (Gambar 2). Sekitar 50\% AVRT ortodromik merupakan AVRT 'manifest' (konduksi dapat terjadi bidireksional), dan 50\% merupakan 'concealed' (hanya terjadi konduksi retrograde). AVRT ortodromik terjadi pada sekitar 95\% AVRT dan 35\% dari semua takikardia supraventrikel (TSV).

\section{AVRT Antidromik}

Pada AVRT antidromik, AP merupakan jalur anterograde dari sirkuit reentri. (Gambar 2). Kompleks QRS pada antidromik terlihat preeksitasi secara penuh (ventrikel teraktivasi dari AP, tanpa kontribusi dari AVN). Pada antidroik yang klasik, konduksi VA retrograde terjadi via AVN. Bentuk non-klasik AVRT antidromik dapat menggunakan AP kedua sebagai jalur retrograde atau kombinasi dengan AVN. Biasanya AVRT antidromik terdapat pada lateral kanan atau kiri sebagai anterograde.
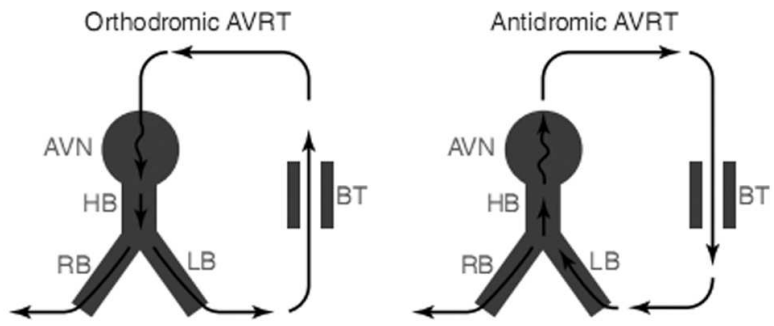

Gambar 2. Skema sirkuit reentri AVRT

\section{Pengukuran non invasif melalui Elektrokardiografi}

\section{Lokasi anatomi AP}

Pada sindrom preeksitasi yang jelas, harus dilakukan pemeriksaan elektrokardiografi sebelum dilakukan prosedur studi elektrofisiologi. Beberapa algoritma telah dikembangkan untuk memperkirakan lokasi anatomi AP berdasarkan polaritas gelombang delta pada permukaan, durasi kompleks QRS, serta aksis atau rasio R/S. Semua algoritma yang sudah ada masing-masing memiliki keterbatasan dalam menilai lokasi yang tepat. Namun beberapa dasar pada penentuan lokasi AP berdasarkan EKG dapat digunakan, antara lain :

a. AP free wall kiri memiliki gelombang delta positif pada seluruh lead prekoardial dan gelombang delta negatif pada lead I dan aVL. Preeksitasi yang berasal dari lateral kiri biasanya diskret.

b. AP free wall kanan memiliki gelombang delta negatif di lead V1 dan V2/V3 dan gelombang delta positif di lead I dan aVL.

c. Jika V1 negatif dan V2 positif ("septal pattern”), hal ini sugestif merupakan AP septal.

d. Posisi posteroseptal memiliki gelombang delta negatif pada lead inferior (II, III, dan aVF)

e. AP anteroseptal menunjukkan gelombang delta positif di lead I, II, III, aVL, dan aVF, serta V5 dan V6.

Algoritma yang saat ini dipakai untuk memprediksi AP anteroseptal ditunjukkan pada gambar $3 .{ }^{1}$ 


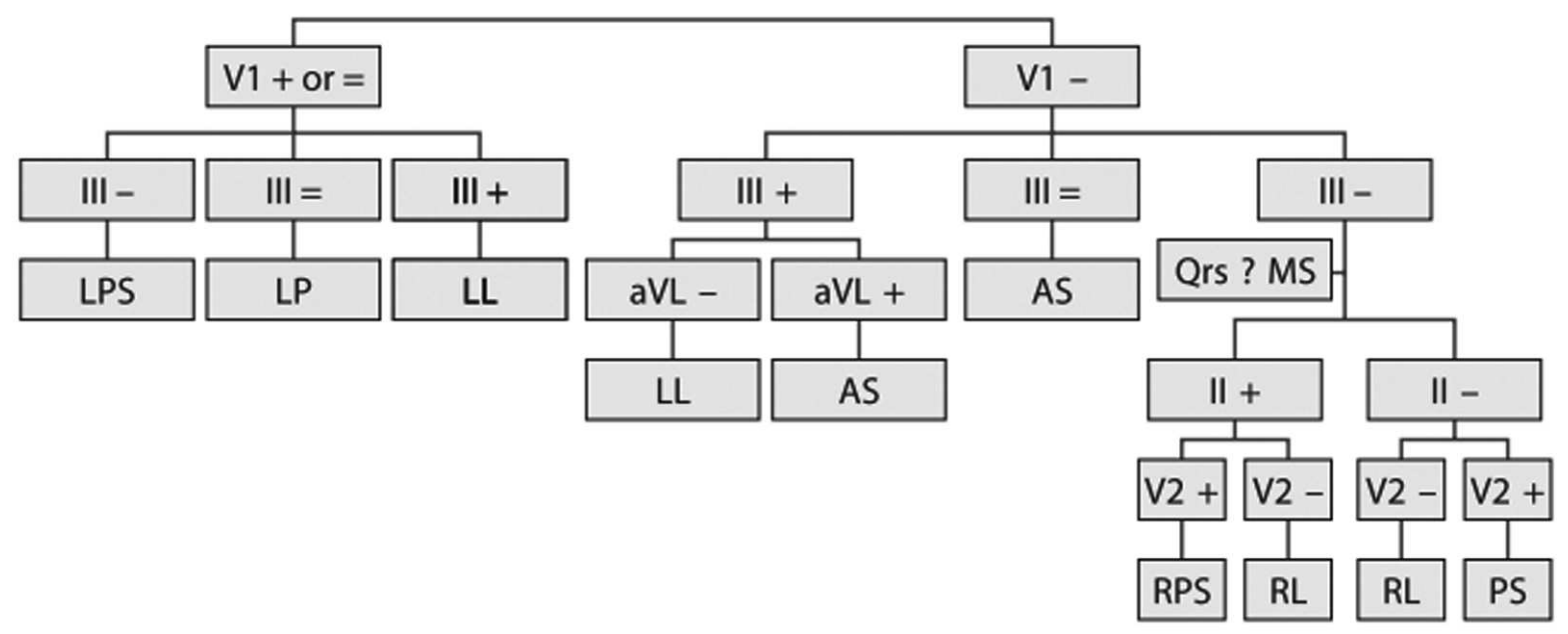

Gambar 3. Algoritma untuk mendeteksi lokasi AP dari EKG (LPS =Left posteroseptal, LP=Left posterior, LL=Left lateral, AS=Anteroseptal, RPS= Right posteroseptal, RL=Right lateral, PS=posteroseptal, MS-Midseptal)

\section{Shortest Pre-Excited R-R Interval (SPERRI)}

Evaluasi non invasif pasien WPW dapat menggunakan EKG saat terjadinya AF preeksitasi sebagai penilaian terhadap konduksi anterograde AP. Pengukuran SPERRI digunakan untuk menentukan konduksi AP. SPERRI 220-250 ms atau lebih sering $<220 \mathrm{~ms}$ sering terlilhat pada pasien WPW yang mengalami henti jantung. Sebaliknya preeksitasi yang intermiten menggambarkan bahwa prediksi kejadian KJM rendah. Fenomena preeksitasi yang intermiten belum dapat sepenuhnya dimengerti, namun berhubungan dengan periode refrakter dari AP dan hubungan antar sel pada AP yang menghasilan konduksi yang variatif. ${ }^{4}$

\section{AP multipel}

Apadanya AP multipel merupakan faktor risiko terhadap terjadinya VF. Adanya AP multipel terlihat dari EKG dengan morfologi preeksitasi yang berbeda-beda. Sekitar 5-10\%npasien dengan WPW memiliki presentasi klini takikardia preeksitasi, yang berarti memiliki konduksi AP anterograde yang baik. ${ }^{4}$

\section{Manifestasi klinis sindrom WPW}

Kebanyakan pasien dengan preeksitasi biasanya asimtomatik dan diketahui pertama kali secara kebetulan. Jika gejala disertai aritmia yang terjadi pada pasien
WPW, dinamakan sindrom WPW. Tipe aritmia yang paling sering terjadi antara lain: ${ }^{6}$

\section{AVRT}

Pasien dengan AVRT biasanya mengalami TSV paroksismal dengan onset dan terminasi yang mendadak dengan gejala palpitasi, nyeri dada, sesak napas, pre sinkop, dan sinkop (jarang). Gejalanya biasanya ringan dan bisa diterminasi dengan manuver Vagal. Namun kadang gejala bisa terlihat berat, terutama jika disertai kelainan struktural jantung

\section{Atrial Fibrilasi}

AP dapat berhubungan dengan pembentukan AF. Mekanisme bagaimana AVRT dapat menimbulkan AF belum sepenuhnya jelas. Laju atrium yang cepat dapat menimbulkan gangguan aktivasi dan reaktivasi atrium, menimbulkan substrat fisiologis yang kondusif untuk AF. Observasi pada pasien dengan AP dan AF yang sembuh dengan ablasi AP, membuktikan hipotesis tersebut. Kemungkinan lain yaitu terjadinya reentri terlokalisir, perubahan hemodinamik, dan regangan atrium juga memiliki peran. Ablasi AP dapat menyembuhkan AF pada lebih dari $90 \%$ pasien.

\section{Kematian jantung mendadak}

VF pada pasien dengan sindrom WPW terjadi kar- 
ena AF dengan respons ventrikel cepat. Insidens kematian jantung mendadak diperkirakan $0,15 \%$ sampai 0,39\% pada 3-10 tahun follow up. Sekitar 50\% dari cardiac arrest pada WPW merupakan presentasi klinis pertama WPW

\section{Tatalaksana sindrom WPW simtomatik}

\section{Fase akut}

Pasien dengan AVRT serupa dengan TSV paroksismal. Pada pasien dengan AVRT ortodromik dan antidromik, pengobatan ditujukan pada AP (ibutilide, procainamide, dan flecainide) atau pada AVN (beta bloker, diltiazem, verapamil), karena keduanya merupakan komponen yang sangat penting pada sirkuit takikardia. Adenosin harus digunakan dengan hati-hati karena dapat memicu AF dengan respons cepat pada pasien dengan preeksitasi. ${ }^{6}$

Blok AVN tidak efektif pada AVRT antidromik AVRT yang memiliki multipel AP sebagai anterograde dan retrograde, karena AVN tidak masuk pada sirkuit reentri. Blok AV harus digunakan dengan hati-hati pada pasien AF, Atrial flutter, AT dengan penyerta AP. Obat antiaritmia seperti ibutilide, flecainide, atau procainamide yang dapat memblok AP lebih disarankan. Jika terapi obat gagal atau hemodinamik tidak stabil, maka harus dipertimbangkan kardioversi. ${ }^{6}$

\section{Fase kronik}

Kateter ablasi merupakan pilihan utama pasien sindrom WPW dengan simtom (kelas I). Terapi ini dapat menyembuhkan lebih dari 95\% pasien dan memliki komplikasi yang rendah.

Pada pasien yang bukan kandidat dilakukan ablasi, obat anti aritmia yang memblok konduksi AP dapat digunakan, seperti blok kanal natrium atau kalium. Beta bloker dapat digunakan dapat digunakan, terutama pada AP dengan konduksi anterograde yang buruk. Verapamil, diltiazem, atau digoxin tidak boleh digunakan untuk terapi jangka panjang pasien dengan AP yang memungkinkan terjadi konduksi cepat selama AF.

Pada pasien dengan 'concealed' AP dan TSV proksismal, kateter ablasi merupakan pilihan utama (Kelas 1). Namun oleh karena 'concelaed' BT tidak berhubungan dengan meningkatnya kematian jantung mendadak, kateter ablasi, atau farmakologis dapat menjadi pilihan pendekatan terapi. Pilihan terapi farmakologis yang dapat dipakai antara lain beta bloker, atau anti aritmia kelas 1 C. ${ }^{6}$

\section{Karakteristik elektrofisiologis sindroma pre eksitasi asimtomatik}

Presentasi klinis WPW biasanya bergantung pada usia dan bervariasi sesuai lokasi AP. AP biasanya ditemukan pada neonatus, namun biasanya lebih disebabkan oleh adanya gangguan integritas elektrik pada anulus AV daripada sebuah AP murni. Meskipun episode TVS menurun pada tahun pertama kehidupan, rekurens takikardia terjadi sekitar $30 \%$ pada usia $7-8$ tahun. ${ }^{4}$

Terdapat bukti-bukti bahwa pada tahun pertama kehidupan, AP kehilangan konduksi anterograde pada sekitar $40 \%$ pasien. Dengan tidak tercetusnya TSV, diperkirakan konduksi AP juga tidak baik secara retrograde. ${ }^{4,7}$ Jika terjadi takikardia pada WPW pada individu usia 5 tahun atau lebih, biasanya akan berlangsung terus pada dekade berikutnya pada $75 \%$ individu. Dewasa muda biasanya muncul dengan gejala aritmia, namun insidensnya sangat rendah. Sekitar 31\% orang dewasa akan kehilangan kapasitas preeksitasi ventrikel dan konduksi anterograde pada periode lebih dari 5 tahun. Hilangnya preeksitasi pada anak dan remaja pada periode 5 tahun sangat bervariasi $(0-26 \%){ }^{4}$

Alasan dilakukan evaluasi studi EP secara invasif pada pasien dengan WPW yang didiagnosis berdasarkan EKG adalah untuk mengidentifikasi adanya peningkatan risiko terjadinya KJM. Pasien dengan preeksitasi intermiten atau AP dengan konduksi anterograde yang decremental memiliki risiko yang lebih rendah terhadap KJM. Pasien dengan konduksi AP retrograde yang buruk juga memliki risiko yang lebih rendah terhadap terjadinya KJM. ${ }^{4}$

\section{Komplikasi sindrom preeksitasi}

Pada studi yang dilakukan oleh Pappone dkk yang dilakukan pada sejumlah populasi yang dilakukan skrining EKG dan dilakukan studi elektrifisiologi, ditemukan bahwa terdapat pasien yang menjadi simtomatik (33 dari 162 pasien, 20,4\%). Pasien-pasien tersebut rata-rata lebih muda daripada yang tidak simtomatik ( $20,1 \pm 8.6$ tahun vs $37.1+13.4$ tahun, 
p<0.0001). Saat studi EP, 29 dari 33 pasien (88\%) tercetus AVRT, dan berubah menjadi AF pada 11 dari 29 pasien. Setelah onset pertama, seluruh pasien terjadi aritmia spontan dalam bentuk TSV pada 25 pasien dan AF pada 8 pasien. Pada pasien yang tidak tercetus takiaritmia saat studi EP, hanya 4 dari 115 pasien terjadi simptom. Terjadinya AF setelah pacu atrial yang cepat pada studi EP bukan merupakan prediktor yang baik untuk memprediksi kemungkinan terjadi takiaritmia. ${ }^{8}$

Pada studi yang dilakukan oleh Teo dkk, diketahui penilaian tercetusnya takikardia, adanya AP multipel merupakan salah satu faktor yang menyebabkan menjadi simtomatik. AP multipel akan meningkatkan risiko terjadinya VF pada WPW yang terlihat pada pasien yang mengalami episode VF. AP efferctive refractory period (ERP) yang pendek juga berhubungan dengan timbulnya gejala, walaupun predikter ini lebih lemah dari AP multipel maupun tercetusnya AVRT. ${ }^{9}$

Preeksitasi ventrikel merupakan penyebab utama dari KJM pada usia muda dan tidak didahului gejala awal pada $40 \%$. AP kiri merupakan substrat yang paling sering, dan berlokasi di subendokard sehingga memudahkan prosedur kateter ablasi. Diketahui bahwa miokarditis atrial yang terisolasi dapat mencetuskan AF paroksismal yang mepengaruhi KJM. ${ }^{10}$

Pada studi meta-analisis baru yang dilakukan oleh Obeyeskere et al mengenai risiko terjadinya aritmia dan kematian jantung mendadak pada pasien dengan preeksitasi yang asimtomatik pada 20 studi besar, didapatkan bahwa insidens terjadinya KJM pada individu hanya sekitar 0.7-4.5 per 1000 tahun-orang. KJM hanya terdokumentasi pada 6 dari 20 studi yang ada. Tidak ada kejadian KJM pada 14 studi lainnya. Kejadian TSV terlihat pada 18 studi. Terdapat 156 pasien dengan kejadian TSV. Laju terjadinya TSV bervariasi antara 0 sampai 50 per 1000 tahun-orang. Studi ini menunjukkan bahwa secara umum risiko terjadinya KJM rendah yaitu $<2,5$ per 1000 tahunorang. Demikian pula risiko terjadinya TSV yang juga rendah, yaitu <25 per 1000 tahun-orang. Diketahui bahwa anak-anak memiliki insidens yang lebih tinggi daripada dewasa. ${ }^{7}$

Perlu dipertimbangkan bahwa efek samping yang serius akibat dilakukan kateter ablasi antara lain adalah blok AV, perforasi jantung, keterlibatan arteri koroner, serta kejadian tromboemboli. ${ }^{7}$ Keputusan yang diambil untuk studi EP atau tidak harus berdasarkan usia, lokasi AP, serta faktor sosial dan personal. Jika kateter ablasi memiliki risiko yang sangat rendah, maka dapat disarankan dilakukan studi EP dan ablasi. ${ }^{11}$ Studi yang diperoleh dari registri ditemukan kejadian komplikasi sebanyak 3,2\%. Blok AV derajat 2 dan 3 terjadi sebanyak 0,7\%.7 Kejadian blok AV ini berkaitan dengan lokasi AP, di mana jika dilakukan ablasi pada AP ParaHisian akan meningkatkan risiko komplikasi tersebut. ${ }^{11}$ Kejadian trombus terjadi pada 0,3\%. Pada studi PAPCA dilaporkan komplikasi sebanyak $4 \%$, RBBB terjadi pada $0,5 \%$, LBBB 0,1\%, regurgitasi katup 0,3\%. Blok AV terjadi pada $0,9 \%$ pasien dengan AP manifest, hanya pada pasien dengan AP septal kanan atau kiri. ${ }^{4}$ Data pasien WPW asimtomatik yang dilakukan kateter ablasi menunjukkan tidak adanya kematian yang terjadi sampai dengan 34 bulan. Tiga dari 57 pasien mengalami TSV. ${ }^{7}$

\section{Algoritma tatalaksana WPW Asimtomatik}

Jika menemukan pasien dengan gambaran EKG WPW yang asimtomatik, langkah pertama yang harus dilakukan adalah evaluasi non invasif untuk stratifikasi risiko. Pada pasien dengan risiko rendah, tidak disarankan melakukan pemeriksaan lain. EKG yang terdokumentasi WPW harus diberikan pada pasien untuk mencegah terjadinya misdiagnosis terhadap infark miokard atau jika terjadi aritmia pada masa yang akan datang. ${ }^{11}$

Rekomendasi dari guideline HRS tahun 2012 menunjukkan algoritma tata laksana pasien dengan pola WPW pada EKG yang asimtomatik yang ditunjukkan oleh gambar 4 .

Pasien dengan EKG WPW manifest yang jelas perlu dilakukan exercise test untuk evaluasi ada nyaepisode hilangnya gambaran WPW saat olahraga. Pasien dengan gambaran WPW yang hilang timbul saat LJ fisiologis memiliki risiko KJM yang sangat rendah. Pada pasien yang tidak dapat dilakukan exercise test, disarankan untuk dilakukan stratifikasi risiko dengan studi EP, misal pada anak-anak yang masih terlalu muda. ${ }^{4}$

Pasien muda dengan SPERRI $<250 \mathrm{~ms}$ saat AF meningkatkan risiko terjadinya KJM, maka ablasi perlu dilakukan pada grup tersebut (Kelas IIA). Sedangkan pasien dengan SPERRI>250 ms memiliki risiko rendah terhadap $\mathrm{KJM}$, sehingga ablasi hanya dipertimbangkan pada pasien jika lokasi AP tidak akan 


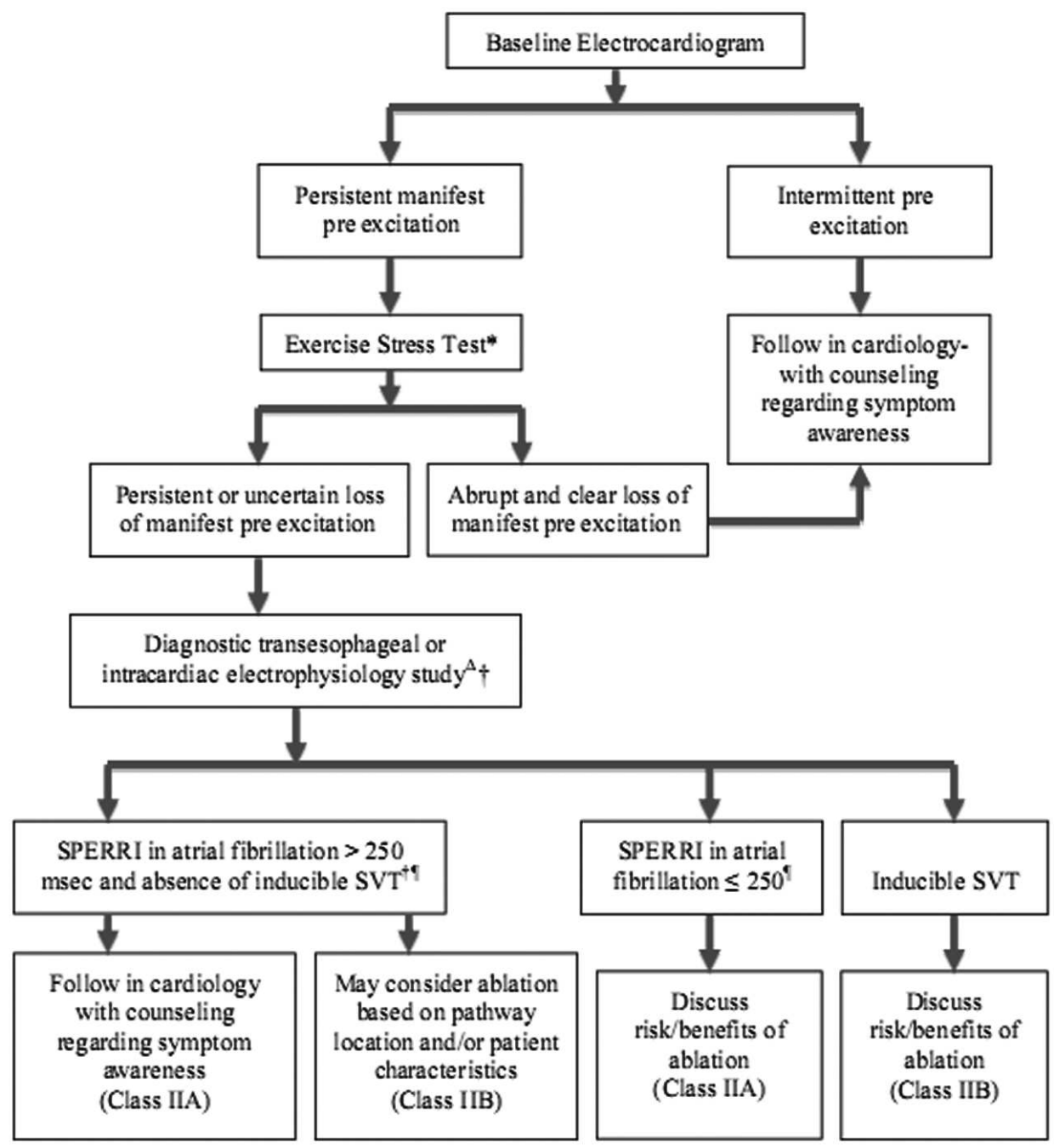

Gambar 4. Algoritma tatalaksana WPW asimtomatik

meningkatkan risiko ablasi seperti blok AV atau injury koroner (kelas IIB). Pasien WPW asimtomatik dengan kelainan struktural jantung meningkatkan risiko terjadinya AT dan AVRT yang akan menyebabkan gangguan hemodinamik. Ablasi dapat dilakukan tanpa memperhatikan karakteristik anterograde AP (Kelas IIB). Pasien WPW asimtomatik dengan disfungsi ventrikel karena disinkroni kontraksi dapat dilakukan ablasi (Kelas IIB). ${ }^{4}$

\section{Ringkasan}

WPW merupakan sindroma preeksitasi ventrikel yang memiliki risiko terjadinya KJM dan aritmia maligna.
Prevalensinya pada populasi diketahui sekitar 1 sampai 3 orang per 1000 individu. Pasien dengan pola WPW pada EKG terbagi menjadi asimtomatik dan simtomatik. Sampai saat ini masih terdapat kontroversial mengenai tatalaksana pasien WPW yang asimtomatik. Dari studi-studi yang telah dilakukan terlihat bahwa kejadian KJM atau aritmia yang mengancam jiwa pada WPW asimtomatik rendah. Namun di sisi lain ditemukan bahwa kejadian komplikasi akibat dilakukannya kateter ablasi juga memiliki risiko yang hampir sama dengan timbulnya KJM atau aritmia pada WPW asimtomatik. Perlu dikomunikasikan pada pasien mengenai risiko terjadinya aritmia dan risiko komplikasi tindakan jika akan dilakukan tindakan studi EP dan kateter ablasi. 


\section{Daftar Pustaka}

1. Helising G, Schneider M, Pustowoit A, Schmitt C. Accessory Pathway. In: Schmitt C, Deisenhofer I, Zrenner B, eds. Catheter ablation of cardiac arrhythmia : A practical approach. Munich: Springer; 2006:77-102.

2. Timmermans C, Smeets JL, Rodriguez LM, Vrouchos G, van den Dool A, Wellens HJ. Aborted sudden death in the WolffParkinson-White syndrome. Am J Cardiol 1995;76:492-4.

3. Klein GJ, Bashore TM, Sellers TD, Pritchett EL, Smith WM, Gallagher JJ. Ventricular fibrillation in the Wolff-ParkinsonWhite syndrome. N Engl J Med 1979;301:1080-5.

4. Cohen MI, Triedman JK, Cannon BC, et al. PACES/HRS Expert Consensus Statement on the Management of the Asymptomatic Young Patient with a Wolff-Parkinson-White (WPW, Ventricular Preexcitation) Electrocardiographic Pattern: Developed in partnership between the Pediatric and Congenital Electrophysiology Society (PACES) and the Heart Rhythm Society (HRS). Endorsed by the governing bodies of PACES, HRS, the American College of Cardiology Foundation (ACCF), the American Heart Association (AHA), the American Academy of Pediatrics (AAP), and the Canadian Heart Rhythm Society (CHRS). Heart Rhythm 2012;9:1006-24.

5. Zipes DP, DiMarco JP, Gillette PC, et al. Guidelines for clinical intracardiac electrophysiological and catheter ablation procedures. A report of the American College of Cardiology/
American Heart Association Task Force on Practice Guidelines (Committee on Clinical Intracardiac Electrophysiologic and Catheter Ablation Procedures), developed in collaboration with the North American Society of Pacing and Electrophysiology. J Am Coll Cardiol 1995;26:555-73.

6. Issa Z, Miller J, Zipes D. Clinical arrhythmology and electrophysiology : a companion to Braunwald's heart disease. In: Issa Z, ed. 1st edition ed. Philadelphia; 2009.

7. Obeyesekere MN, Leong-Sit P, Massel D, et al. Risk of arrhythmia and sudden death in patients with asymptomatic preexcitation: a meta-analysis. Circulation 2012;125:2308-15.

8. Pappone C, Santinelli V, Rosanio S, et al. Usefulness of invasive electrophysiologic testing to stratify the risk of arrhythmic events in asymptomatic patients with Wolff-Parkinson-White pattern: results from a large prospective long-term follow-up study. J Am Coll Cardiol 2003;41:239-44.

9. Teo WS, Klein GJ, Guiraudon GM, et al. Multiple accessory pathways in the Wolff-Parkinson-White syndrome as a risk factor for ventricular fibrillation. Am J Cardiol 1991;67:889-91.

10. Basso C, Corrado D, Rossi L, Thiene G. Ventricular preexcitation in children and young adults: atrial myocarditis as a possible trigger of sudden death. Circulation 2001;103:269-75.

11. Wellens HJ. Should catheter ablation be performed in asymptomatic patients with Wolff-Parkinson-White syndrome? When to perform catheter ablation in asymptomatic patients with a Wolff-Parkinson-White electrocardiogram. Circulation 2005;112:2201-7; discussion 16. 